\title{
Implementasi Theory of Planned Behavior terhadap Entrepreneurial Intention: Efek Moderasi Entrepreneurship Education dan Gender
}

\author{
Okto Aditya Suryawirawan*, Wiwiek Srikandi Shabrie, Krido Eko Cahyono \\ Sekolah Tinggi Ilmu Ekonomi Indonesia Surabaya, Surabaya, Indonesia \\ *oktoaditya@stiesia.ac.id
}

\begin{abstract}
The aim of this study is to analyze the effect of entrepreneurship education on the entrepreneurial intention of college students in Surabaya. Purposive sampling was used towards 220 college students. The criteria of the samples were students who already took entrepreneurship subject for bachelor degree and entrepreneurship practicum for vocational studies. This study used Mann-Whitney U-Test through SPSS and partial least squares through SmartPLS. This study finds: 1) attitude, subjective norm and perceived behavioral control have a positive significant impact towards entrepreneurial intention, 2) entrepreneurship education has a positive significant impact towards entrepreneurial intention,3) entrepreneurship education failed to moderate any of the theory of planned behavior variables effect toward entrepreneurial intention, 4) gender failed to moderate the relationship between entrepreneurship education and entrepreneurial intention, 5) there was no difference on the level of entrepreneurial intention between male and female college students, 6) there was no difference on the level of entrepreneurial intention between bachelor degree and vocational studies students.
\end{abstract}

Keywords: Entrepreneurship Education, Entrepreneurial Intention, Gender, Theory of Planned Behavior

\section{PENDAHULUAN}

Kewirausahaan di Indonesia telah memperoleh perhatian khusus dari pemerintah selama dua dekade terakhir. Sejak krisis ekonomi pada tahun 1998, kewirausahaan dipandang menjadi solusi yang paling baik dalam mengatasi jumlah lapangan kerja yang terbatas dan tingginya angka pengangguran di Indonesia. Berdasarkan data yang diperoleh dari Badan Pusat Statistik, pengangguran di Indonesia mencapai 7 juta sedangkan jumlah wirausaha di Indonesia masih di angka 3\% (Badan Pusat Statistik, 2019). Ini menandakan bahwa potensi kewirausahaan dalam upaya mengurangi angka pengangguran di
Indonesia khususnya Surabaya masih sangat tinggi.

Memberikan stimulus yang dapat menimbulkan ketertarikan sesorang terhadap pendirian usaha menjadi hal yang penting, khususnya bagi negara berkembang seperti Indonesia. Peran kewirausahaan sangat besar dalam mempercepat perkembangan ekonomi, melalui penciptaaan ide bisnis dengan berbagai inovasi, yang kemudian mengarah pada penciptaan usaha. Dengan meningkatnya jumlah usaha tersebut, diharapkan dapat meningkatkan lapangan kerja dan kompetisi pada pasar (Ozaralli \& Rivenburgh, 2016). Sayangnya mayoritas elemen penggerak pertumbuhan ekonomi nasional di Indonesia masih didominasi 
perusahaan yang sudah ada dibandingkan dengan perusahaan baru (Billah, 2019).

E-commerce kini juga tidak dapat dipungkiri telah menjadi salah satu opsi bagi wirausaha-wirausaha baru untuk memulai usahanya. Sejalan dengan teknologi di era digital yang terus berkembang, e-commerce di Indonesia juga ikut tumbuh dengan sangat pesat. Ekonomi digital Indonesia berhasil menyumbangkan kontribusi mencapai $49 \%$ di kawasan Asia Tenggara pada tahun 2018 (Rahayu, 2019), hal ini wajar adanya bila melihat data statistik bahwa 98,6\% dari populasi di Indonesia telah mengetahui tentang adanya kegiatan jual beli secara online (APJII, 2017). Melihat mudah dan murahnya akses terhadap pemasaran dan juga pasar, serta metode penjualannya yang sudah tidak terbatas oleh lokasi, menjadi wirausaha melalui e-commerce seharusnya menjadi hal yang dapat menarik perhatian mahasiswa untuk menjadikan wirausaha pilihan profesi yang potensial di masa depan.

Pemerintah telah berusaha meningkatkan jumlah wirausaha yang ada di Indonesia melalui berbagai program yang mengarah kepada pengembangan UMKM seperti Program Bantuan Dana Bagi Pengembangan Wirausaha Pemula yang dicetuskan oleh Kementrian Koperasi dan UKM (UKM Indonesia, 2019). Pada sektor $e$ commerce pemerintah juga telah mencoba untuk memberikan stimulus terhadap usaha digital di Indonesia dengan Gerakan 1000 Startup pada tahun 2018 oleh Kementrian Komunikasi dan Informatika (Rizkinaswara, 2018). Namun strategi pemerintah melalui program tersebut tentu tidak akan berjalan dengan maksimal tanpa adanya insan-insan muda yang kreatif dan memiliki mindset kewirausahaan. Oleh karena itu sejak tahun 1995, pendidikan kewirausahaan juga ditanamkan mulai dari pendidikan dasar hingga perguruan tinggi (Susilaningsih, 2015). Tidak hanya itu, pemerintah juga mencetuskan Program Mahasiswa Wirausaha oleh Kementrian Pendidikan dan Kebudayaan yang telah dilakukan sejak tahun 2009 (Hendarman, 2011). Manfaat yang dapat diperoleh dari pendidikan khususnya kewirausahaan, didukung oleh sejumlah penelitian terdahulu yang menyatakan bahwa kualitas seorang wirausaha dapat diperoleh dan dikembangkan melalui kegiatan pendidikan dan pelatihan (Ajzen, 1991; Bryant, 2006; Chen et al., 1998; Krueger Jr et al., 2000; Kundu \& Rani, 2008; Xiaoxing, 2020). Pernyataan tersebut juga didukung oleh penelitian sebelumnya yang menyatakan bahwa pendidikan kewirausahaan merupakan sebuah platform yang memberikan kontribusi pada ekonomi global melalui peningkatan kuantitas dan kualitas wirausaha (Bae et al., 2014). Penelitian lain juga menyatakan bahwa pendidikan kewirausahaan dapat meningkatkan entrepreneurship awareness dan memberikan inspirasi terhadap individu yang memiliki potensi menjadi wirausaha (Hua \& Ren, 2020). Kendatipun begitu, dengan melihat populasi wirausaha yang pergerakannya sangat lambat selama hampir tiga dekade ini di Indonesia, perlu dikaji kembali seberapa efektif program-program yang dicanangkan tersebut khususnya matakuliah Kewirausahaan pada perguruan tinggi yang dijadikan objek penelitian, dalam meningkatkan minat mahasiswa untuk menjadikan wirausaha, sebagai sebuah pilihan profesi ketika mereka lulus nanti.

\section{Entrepreneurship Education pada Entrepreneurial Intention}

Definisi dari entrepreneur adalah seseorang yang ingin menciptakan value, melalui serangkaian aktifitas ekonomi, dengan melakukan identifikasi dan eksploitasi produk, proses, ataupun pasar yang baru, sedangkan entrepreneurship adalah fenoma terkait dengan serangkaian aktifitas yang dilakukan oleh entrepreneur tersebut (Stokes et al., 2010). Fungsi daripada entrepreneurship education kemudian adalah memberikan pelajar dari berbagai tingkatan pendidikan pengetahuan, keterampilan dan motivasi yang mampu mendukung kesuksesan dalam berwirausaha pada berbagai situasi di masa yang akan datang (Fiore et al., 2019).

Serangkaian penelitian sebelumnya menekankan pada kesulitan yang dihadapi 
dalam melakukan evaluasi terhadap manfaat dari entrepreneurship education. Penelitian sebelumnya menyatakan bahwa belum ada dukungan penelitian empiris terhadap bagaimana formal entrepreneurial initiative dan SME (small medium enterprises) courses dapat meningkatkan probabilitas seseorang untuk memulai sebuah bisnis (Henry et al., 2005). Sejalan dengan penelitian tersebut penelitian lain juga menyatakan bahwa kontribusi yang riil dari entrepreneurship education masih belum tampak secara jelas (Hoang et al., 2021; Johnstone et al., 2018; Matlay, 2005; Pittaway \& Cope, 2007). Berdasarkan paparan tersebut maka penelitian ini mencoba untuk menganalisis lebih dalam terkait dampak entrepreneurship education pada entrepreneurship intention.

Berdasarkan penelitian sebelumnya, ditemukan bahwa minat mahasiswa terhadap pilihan profesi wirausaha yang rendah, dikarenakan mindset mahasiswa yang masih cenderung memilih untuk bekerja (Atmaja \& Margunani, 2016; Hartono, 2021; Lelliezzia et al., 2020), meskipun telah dibekali kurikulum kewirausahaan selama mereka masih menduduki bangku kuliah. Hal ini dapat disebabkan oleh kurikulum kewirausahaan yang masih menitik beratkan pada teori dibandingkan dengan kegiatankegiatan inovatif, sehingga kurang dapat memberikan kontribusi terhadap berkembangnya mindset berwirausaha pada mahasiswa. Ciri dari kurikulum yang masih berkutat terbatas pada teori tersebut juga ditemukan pada pendidikan tingkat sarjana yang ada pada objek penelitian ini. Berdasarkan paparan tersebut maka penelitian ini dilakukan dengan tujuan untuk menganalisis pengaruh pendidikan kewirausahaan yang ada pada perguruan tinggi tersebut, terhadap minat wirausaha mahasiswa.

Selain matakuliah kewirausahaan pada jenjang pendidikan sarjana yang dipaparkan diatas, pada perguruan tinggi yang diteliti terdapat matakuliah praktikum kewirausahaan yang khusus diberikan untuk jenjang pendidikan vokasi. Matakuliah tersebut dapat diambil setelah mahasiswa selesai menempuh matakuliah kewirausahaan pada semester sebelumnya. Matakuliah praktikum kewirausahaan khusus diberikan kepada jenjang vokasi dalam rangka memberikan kontribusi terhadap lapangan kerja industri dengan profil lulusan dengan ketrampilan dan pengetahuan tinggi sesuai dengan rencana strategis Direktorat Jendral Pendidikan Vokasi tahun 2020-2024 (Ditjen Pendidikan Vokasi, 2020), yang dalam penelitian ini khususnya dalam hal berwirausaha. Pernyataan diatas juga didukung oleh serangkaian penelitian terdahulu yang menyatakan bahwa kegiatan ekstrakurikuler, matakuliah opsional dan aktifitas praktikum terkait kewirausahaan, dapat mempengaruhi niatan berwirausaha seseorang (Arranz et al., 2017; Duval-Couetil et al., 2016; Hien \& Cho, 2018; Karimi et al., 2016; Nguyen et al., 2021; Piperopoulos \& Dimov, 2015).

Melalui matakuliah kewirausahaan yang diberikan di jenjang perguruan tinggi, penelitian ini mencoba menganalisis dampak dari pendidikan tersebut terhadap niatan mahasiswa untuk menjadi wirausaha. Penelitian ini juga diharapkan dapat melihat kemungkinan terdapatnya perbedaan antara mahasiswa yang hanya menempuh matakuliah kewirausahaan dengan mahasiswa yang juga menempuh praktikum kewirausahaan, pada niatan mereka untuk berwirausaha setelah lulus nanti. Berdasarkan serangkaian studi empiris yang telah dilakukan, keberadaan pendidikan terbukti memiliki pengaruh yang positif terhadap niatan seseorang untuk menjadi wirausaha (Athayde, 2009; Ferreira et al., 2012; Jun, 2016). Penelitian terdahulu juga menyatakan bahwa kewirausahaan sebagai sebuah program pendidikan, dapat membantu membangun kesadaran seseorang akan potensi kewirausahaan, sebagai sebuah pilihan karir secara positif (Anderson \& Jack, 2008). Berdasarkan pemaparan diatas maka disusun hipotesis sebagai berikut:

$\mathrm{H}_{1 \mathrm{a}}$ : Entrepreneurship education berpengaruh positif terhadap entrepreneurial intention 
$\mathrm{H}_{1 \mathrm{~b}}$ : Entrepreneurial intention mahasiswa yang menempuh praktikum kewirausahaan lebih tinggi dibandingkan dengan yang tidak menempuh

\section{Theory of Planned Behavior pada Entrepreneurial Intention}

Theory of planned behavior dikembangkan dari theory of reasoned action akibat keterbatasan teori tersebut dalam menjelaskan behavior yang berada diluar kendali seseorang (Ajzen \& Fishbein, 1980; Fishbein \& Ajzen, 1975). Sama halnya dengan theory of reasoned action, faktor penting yang ada pada theory of planned behavior adalah niatan individu untuk menunjukkan perilaku yang spesifik (Ajzen, 1991). Niatan yang dimiliki oleh seseorang mengandung faktor yang mampu memotivasi terjadinya sebuah perilaku dari orang tersebut. Semakin kuat niatan seseorang semakin kuat perilaku yang ditunjukkan. Theory of planned behavior kemudian menyimpulkan bahwa terdapat tiga hal yang menentukan niatan yang muncul pada seseorang, yaitu attitude, subjective norm dan perceived behavioral control (Ajzen, 1991).

Attitude adalah kecenderungan individu dalam memberikan evaluasi positif atau negatif pada suatu hal (Eagly \& Chaiken, 1993). Niat, yang dipengaruhi oleh sikap, terkait perwujudan atas perilaku yang spesifik, memiliki kemungkinan untuk menjadi indikator kuat terhadap manifestasi perilaku yang dimaksud (Fishbein \& Ajzen, 1975). Attitude seseorang terhadap masalah tertentu bergantung pada kepercayaan orang tersebut terhadap outcome yang dihasilkan (Shook \& Bratianu, 2010). Attitude seseorang terhadap aktifitas bisnis dapat berupa attitude yang positif ataupun negatif. Attitude kemudian dapat juga diartikan sebagai sejauh mana respon seseorang baik positif maupun negatif terhadap situasi yang terjadi disekitar bisnis (Lucky \& Minai, 2014). Outcome memegang peranan penting terhadap terbentuknya attitude seseorang, dalam arti bila outcome yang didapatkan semakin positif maka persepsi orang tersebut juga akan menjadi semakin positif, hal ini kemudian mampu meningkatkan niatan orang tersebut untuk melakukan kegiatan yang berkaitan dengan outcome yang diharapkan (Shook \& Bratianu, 2010). Pada konteks penelitian ini, outcome yang dimaksud adalah entrepreneurial intention, sehingga bila seorang individu merasa bahwa pendirian usaha adalah sebuah hal yang positif, maka berdasarkan pernyataan tersebut, attitude terhadap pendirian usaha juga akan positif.

Subjective norm didefinisikan sebagai sejauh mana individu mendukung (atau tidak mendukung) hasil tindakan tertentu. Dalam serangkaian penelitian yang telah dilakukan, subjective norm diukur dengan mengajukan pertanyaan terhadap responden terkait sejauh mana orang yang berhubungan erat dengan mereka (keluarga, teman, atau kolega), mendukung kegiatan yang mereka lakukan. Dalam penelitian ini kegiatan yang dimaksud merupakan aktifitas penciptaan usaha (venture creation) (Ajzen, 2001; Liñán \& Chen, 2009). Jika seorang individu menganggap bahwa orang yang berperan signifikan disekitarnya, mendukung (atau tidak mendukung) perilaku yang ditunjukkan maka itu akan mempengaruhi perwujudan dari perilaku tersebut. Berdasarkan paparan tersebut kemudian dapat disimpulkan bahwa subjective norm adalah salah satu bentuk tekanan sosial dari keluarga, teman, dan pihak lain yang signifikan bagi kehidupan seseorang (Ajzen, 1991). Berdasarkan pernyataaan tersebut, dapat disimpulkan bahwa dukungan keluarga, teman dan kolega responden memiliki pengaruh yang besar terhadap tindakan yang akan dilakukan, yang dalam konteks penelitian ini adalah entrepreneurial intention. Semakin besar dukungan orang yang berada disekitar responden maka berdasarkan pemaparan sebelumnya, niatan seseorang untuk mendirikan usaha juga akan semakin besar.

Perceived behavioral control dan juga behavioral intention merupakan suatu instrument yang mampu memprediksi pencapaian seseorang akan suatu hal (Ajzen, 1991). Perceived behavioral control didefinisikan sebagai anggapan akan 
kemudahan atau kesulitan yang dihadapi dalam melakukan suatu kegiatan (Ajzen, 1991). Dalam penelitian ini hal yang dimaksud adalah mengenai mendirikan dan menjalankan usaha. Perceived behavioral control merupakan bagian dari theory of planned behavior yang menyatakan bahwa bersama dengan behavioral intention, dapat memprediksi dengan baik pencapaian seseorang akan sesuatu (Ajzen, 1991).

Dinyatakan pada penelitian terdahulu bahwa perceived behavioral control dapat memprediksi perilaku dan niatan secara langsung, karena perasaan memiliki kendali atas sesuatu pada diri seseorang, dapat meningkatkan kemauan orang tersebut dalam memberikan usaha yang lebih agar dapat mencapai kesuksesan (Armitage \& Conner, 2001). Berdasarkan pernyataan tersebut maka dapat disimpulkan bahwa pada konteks penelitian yang dilakukan, perasaan mampu untuk mendirikan sebuah usaha akan meningkatkan kemauan seseorang untuk merealisasikan pendirian usaha tersebut meskipun harus dengan usaha yang lebih.

Dinyatakan dalam Theory of planned behavior bahwa intention yang diikuti oleh action, ditentukan oleh attitude, subjective norm dan perceived behavioral control (Ajzen, 1991; Bird, 1988; Gartner \& Katz, 1988). Berdasarkan pernyataan tersebut dapat disimpulkan bahwa pada konteks penlitian yang dilakukan, tindakan pendirian usaha sangat dipengaruhi oleh niatan seseorang yang terbentuk dari attitude, subjective norm, dan perceived behavioral control yang ada dalam diri orang tersebut. Mengacu pada sejumlah penelitian sebelumnya yang menunjukkan pengaruh signifikan attitude, subjective norm dan perceived behavioral control terhadap entrepreneurial intention (Aloulou, 2016; Dinc \& Budic, 2016; Yang, 2013), penelitian ini ingin melihat dampak theory of planned behavior dengan moderasi entrepreneurship education pada niatan untuk mendirikan usaha, baik pada program studi sarjana maupun vokasi di perguruan tinggi yang diteliti.
Berdasarkan berbagai pemaparan sebelumnya maka disusun hipotesis sebagai berikut:

$\mathrm{H}_{2}$ : Attitude memberikan pengaruh positif terhadap entrepreneurial intention

$\mathrm{H}_{3}$ : Subjective norm memberikan pengaruh positif terhadap entrepreneurial intention

$\mathrm{H}_{4}$ : Perceived behavioral control memberikan pengaruh positif terhadap entrepreneurial intention

$\mathrm{H}_{5 \mathrm{a}}$ : Pengaruh attitude terhadap entrepreneurial intention dimoderasi oleh entrepreneurship education

$\mathrm{H}_{5 \mathrm{~b}}$ : Pengaruh subjective norm terhadap entrepreneurial intention dimoderasi oleh entrepreneurship education

$\mathrm{H}_{5 \mathrm{c}}$ : Entrepreneurship education menjadi moderator pada pengaruh perceived behavioral control terhadap entrepreneurial intention

\section{Gender dan Entrepreneurial Intention}

Secara global, jumlah perempuan yang menjadi wirausaha lebih sedikit dibandingkan laki-laki (GEM, 2018). Hal ini juga terefleksi pada jumlah wirausaha perempuan di Indonesia, dimana walaupun perempuan memegang $49 \%$ dari populasi penduduk yang berjumlah 268 juta, dari jumlah tersebut baru sekitar $11 \%$ yang menjadi wirausaha (Badan Pusat Statistik, 2017). Ini menunjukkan potensi yang masih sangat besar bagi wirausaha perempuan. Oleh karena itu penilitian ini juga dilakukan untuk melihat akan kemungkinan terdapatnya perbedaan antara minat berwirausaha pada laki-laki dibandingkan perempuan baik pada program studi sarjana maupun vokasi di perguruan tinggi yang diteliti. Berdasarkan pernyataan sebelumnya maka disusun hipotesis sebagai berikut:

$\mathrm{H}_{6 \mathrm{a}}$ : Entrepreneurial intention pada mahasiswi ditemukan lebih tinggi dibandingkan mahasiswa

$\mathrm{H}_{6 \mathrm{~b}}$ : Pengaruh entrepreneurship education terhadap entrepreneurial intention dimoderasi oleh gender 
Penelitian ini dilakukan dengan mengacu pada penelitian terdahulu yang menemukan bahwa entrepreneurship education berpengaruh signifikan positif terhadap entrepreneurial intention (Jun, 2016). Namun lain halnya dengan penelitian tersebut, penelitian ini juga melihat pengaruh entrepreneurship education pada dua jenjang yang berbeda yaitu sarjana dan vokasi, dengan mempertimbangkan bahwa vokasi memiliki matakuliah yang lebih spesifik pada kegiatan praktikum, yaitu praktikum kewirausahaan. Penelitian ini dilakukan juga dengan mengacu pada penelitian lain yang menunjukkan bahwa subjective norm dan perceived behavioral control memberikan pengaruh yang positif terhadap e-commerce intention (Suryawirawan, 2020) dan pengaruh positif attitude, subjective norm serta perceived behavioral control pada entrepreneurial intention (Dinc \& Budic, 2016). Namun berbeda dengan penelitian diatas, penelitian ini mengikutsertakan variabel entrepreneurship education sebagai variabel moderasi yang diharapkan mampu meningkatkan pengaruh theory of planned behavior pada entrepreneurial intention. Pada penelitian sebelumnya ditemukan bahwa mahasiswi terbukti memiliki entrepreneurial intention yang lebih tinggi dibandingkan mahasiswa (Suryawirawan, 2020), namun penelitian lain justru memperlihatkan hasil sebaliknya (Nowiński et al., 2017). Oleh karena itu penelitian ini ingin melihat kembali pengaruh gender terhadap entrepreneurial intention. Selain itu gender pada penelitian ini juga dilihat sebagai variabel moderasi terhadap pengaruh entrepreneurship education terhadap entrepreneurial intention.

\section{METODE}

Batasan populasi dan sampel pada penelitian ini adalah mahasiswa yang menempuh matakuliah kewirausahaan dan praktikum kewirausahaan. Metode pengambilan sampel yang digunakan adalah non-probability purposive sampling dimana kuisioner diberikan kepada mahasiswa di Surabaya yang pernah menempuh matakuliah kewirausahaan

dan

praktikum

kewirausahaan.

Bedasarkan pernyataan serangkaian penelitian terdahulu, $\mathrm{R}^{2}$ yang dianggap cukup untuk menjelaskan sebuah variabel setidaknya memiliki nilai lebih dari 0,25 (Chin, 1998; Falk \& Miller, 1992; Hair et al., 2014). Menurut penelitian sebelumnya, ukuran sample yang direkomendasikan agar tercapai statistical power sebesar $80 \%$ pada penelitian yang memiliki paling banyak 5 panah yang menuju satu variabel adalah 205 responden untuk tingkat signifikansi $1 \%$ dengan $\mathrm{R}^{2}$ setidaknya 0,10 . Maka dari itu setidaknya 205 responden dibutuhkan untuk melakukan pengujian.

Skala yang digunakan telah dimodifikasi menjadi 4 tingkat dalam rangka mengeliminasi kelemahan pada skala 5 tingkat, karena berdasarkan penelitian terdahulu poin netral seringkali digunakan ketika responden tidak yakin dengan pilihannya. Modifikasi ini juga dilakukan untuk menghindari central tendency sehingga arah dari jawaban responden dapat terlihat dengan lebih jelas (Kulas, 2008; Tsang, 2012). Pada penelitian ini Uji Beda dilakukan dengan menggunakan Mann-Whitney U-Test melalui SPSS dan Partial Least Square melalui software SmartPLS.

\section{HASIL DAN PEMBAHASAN \\ Pengujian Instrumen Penelitian}

Hasil uji validitas instrumen menunjukkan bahwa keseluruhan butir pertanyaan pada masing-masing variabel penelitian memiliki $r$ hitung $>0,50$ sehingga dapat disimpulkan seluruh butir pertanyaan yang mengukur variabel penelitian dikatakan valid. Dari hasil uji reliabilitas instrumen diperoleh koefisien cronbach alpha masingmasing variabel $>0,70$ sehingga dapat disimpulkan butir pertanyaan yang digunakan untuk mengukur variabel penelitian dikatakan reliabel.

Tabel 1. Uji Instrumen Penelitian

\begin{tabular}{lccc}
\hline Variabel & Item & $\begin{array}{c}\mathrm{r} \\
\text { hitung }\end{array}$ & $\begin{array}{c}\text { Cronbach } \\
\text { Alpha }\end{array}$ \\
\hline Attitude & Att1 & 0,864 & 0,822 \\
& Att2 & 0,769 &
\end{tabular}




\begin{tabular}{llcc}
\hline Variabel & Item & $\begin{array}{c}\mathrm{r} \\
\text { hitung }\end{array}$ & $\begin{array}{c}\text { Cronbach } \\
\text { Alpha }\end{array}$ \\
\hline \multirow{3}{*}{ Subjective Norm } & Att3 & 0,948 & \\
& SN1 & 0,785 & 0,718 \\
& SN2 & 0,752 & \\
SN3 & 0,698 & \\
Perceived & SN4 & 0,748 & \\
Cehavioral & PBC1 & 0,651 & 0,759 \\
Control & PBC2 & 0,580 & \\
& PBC3 & 0,698 & \\
& PBC4 & 0,811 & \\
Entrepreneurship & PBC5 & 0,604 & \\
Education & PBC6 & 0,603 & \\
& EE2 & 0,558 & \\
& EE3 & 0,818 & 0,800 \\
Entreprenurial & EE4 & 0,733 & \\
Intention & EE5 & 0,768 & \\
& EI2 & 0,615 & 0,754 \\
& EI3 & 0,705 & \\
& EI4 & 0,821 & \\
& EI5 & 0,701 & \\
\hline
\end{tabular}

Dari 220 responden penelitian, sebagian besar yaitu 136 orang (62\%) tidak menempuh praktikum kewirausahaan, hanya 84 orang (38\%) yang menempuh praktikum kewirausahaan. Dilihat dari usia, sebagian besar responden penelitian berusia 20-21 tahun sebanyak 131 orang $(60 \%)$, responden berusia 18-19 tahun ada 45 orang (21\%), responden berusia 22-23 tahun ada 37 orang (17\%), sedangkan responden berusia 24-25 tahun dan 28-29 tahun masing-masing hanya 5 orang $(2 \%)$ dan 2 orang (1\%). Dari segi jenis kelamin diketahui sebagian besar responden penelitian adalah perempuan yaitu 145 orang (66\%), sedangkan responden laki-laki ada 75 orang $(34 \%)$.

\section{Pengujian Hipotesis}

\section{Uji Mann-Whitney antara entreprenurial intention mahasiswa} mahasiswi yang menempuh praktikum kewirausahaan dan entreprenurial intention mahasiswa mahasiswi yang tidak menempuh praktikum kewirausahaan menghasilkan nilai signifikansi sebesar $0,125>0,05$ menyimpulkan bahwa tidak terdapat perbedaan yang signifikan antara entreprenurial intention mahasiswa mahasiswi yang menempuh praktikum kewirausahaan dan entreprenurial intention mahasiswa mahasiswi yang tidak menempuh praktikum kewirausahaan. Berdasarkan hasil ini $\mathrm{H}_{1 \mathrm{~b}}$ ditolak.

Tabel 2. Uji Beda

\begin{tabular}{lllr}
\hline Variabel & Mean & & $\begin{array}{c}\text { Mann- } \\
\text { Whitney }\end{array}$ \\
\hline & Menempuh & & \\
Entreprenurial & Praktikum & 3,06 & \\
Tidention & menempuh & & 0,125 \\
& praktikum & 3,15 & \\
& Mahasiswa & 3,13 & \multirow{2}{*}{0,926} \\
& Mahasiswi & 3,11 & \\
\hline
\end{tabular}

Uji Mann-Whitney antara entreprenurial intention mahasiswa dan entreprenurial intention mahasiswi menghasilkan nilai signifikansi sebesar 0,926 $>0,05$ menyimpulkan bahwa tidak terdapat perbedaan yang signifikan antara entreprenurial intention mahasiswa dan entreprenurial intention mahasiswi. Berdasarkan hasil ini $\mathrm{H}_{6 \mathrm{a}}$ ditolak.

Dari hasil uji convergent validity diketahui terdapat 10 indikator yang menunjukkan nilai loading factor $<0,70$ sehingga dinyatakan tidak memenuhi convergent validity atau tidak valid. Kesepuluh indikator tersebut adalah Att2, SN2, SN4, PBC2, PBC5, PBC6, PBC7, EE3, EI1 dan EI2. Indikator yang tidak memenuhi convergent validity selanjutnya direduksi dan dilakukan pengujian lagi. Setelah dilakukan reduksi, keseluruhan indikator memenuhi convergent validity atau valid dengan nilai loading factor $>0,70$.

Pada pengujian discriminant validity, nilai $\sqrt{ }$ AVE terkecil ditemukan 0,801 , ketika nilai korelasi terbesar ditemukan 0,669. Hasil ini menunjukkan bahwa seluruh $\sqrt{ }$ AVE bernilai lebih besar dari nilai korelasi antar variabel, sehingga disimpulkan discriminant validity variabel penelitian menunjukkan hasil yang baik. Composite reliability seluruh variabel yang digunakan dalam penelitian ini bernilai > 0,70 menyimpulkan bahwa variabel penelitian telah memenuhi internal consistency atau reliabel.

Diketahui nilai $\mathrm{R}^{2} \quad$ variabel entreprenurial intention sebesar 0,550 yang 
berarti bahwa persentase besarnya entreprenurial intention yang mampu dijelaskan oleh attitude, subjective norm, perceived behavioral control, entrepreneurship education dan gender adalah sebesar $55,9 \%$, lalu $44,1 \%$ sisanya dijelaskan variabel lain di luar model penelitian. Nilai $\mathrm{Q}^{2}$ predictive relevance yang diperoleh sebesar $0,408>0$, ini memperlihatkan bahwa model memiliki predictive relevance yang baik.

Tabel 3. Goodness of Fit

\begin{tabular}{|c|c|c|c|c|c|c|c|}
\hline $\begin{array}{l}\text { Variabel: } \\
\text { Indikator }\end{array}$ & $\begin{array}{c}\text { Loadi } \\
n g *)\end{array}$ & $\begin{array}{l}\text { Loadi } \\
n g * *)\end{array}$ & $\begin{array}{c}\text { AVE } \\
* *)\end{array}$ & $\begin{array}{c}\sqrt{ } \mathrm{AV} \\
\mathrm{E}\end{array}$ & $\begin{array}{c}\text { Comp } \\
\text { osite } \\
\text { Relia } \\
\text { bility } \\
* *)\end{array}$ & $\mathrm{R}^{2}$ & $\begin{array}{c}\mathrm{Q}^{2} \\
\text { Pred. } \\
\text { Rel. }\end{array}$ \\
\hline Att : Att1 & 0,875 & 0,913 & 0,788 & 0,887 & 0,881 & & \\
\hline $\operatorname{Att} 2 * * *)$ & 0,605 & & & & & & \\
\hline Att3 & 0,853 & 0,861 & & & & & \\
\hline SN : SN1 & 0,851 & 0,874 & 0,783 & 0,885 & 0,878 & & \\
\hline SN2***) & 0,068 & & & & & & \\
\hline SN3 & 0,872 & 0,896 & & & & & \\
\hline SN4***) & 0,465 & & & & & & \\
\hline PBC : & & & & & & & \\
\hline PBC1 & 0,775 & 0,846 & 0,702 & 0,838 & 0,876 & & \\
\hline $\mathrm{PBC} 2 * * *)$ & 0,324 & & & & & & \\
\hline $\mathrm{PBC} 3$ & 0,793 & 0,869 & & & & & \\
\hline PBC4 & 0,774 & 0,796 & & & & & \\
\hline PBC5***) & 0,437 & & & & & & \\
\hline PBC6***) & 0,494 & & & & & & \\
\hline PBC7***) & 0,333 & & & & & & \\
\hline EE : EE1 & 0,785 & 0,790 & 0,642 & 0,801 & 0,877 & & \\
\hline EE2 & 0,751 & 0,756 & & & & & \\
\hline EE3***) & 0,254 & & & & & & \\
\hline EE4 & 0,807 & 0,805 & & & & & \\
\hline EE5 & 0,853 & 0,850 & & & & & \\
\hline EI : & & & & & & & \\
\hline EI1 $* * *)$ & 0,245 & & 0,782 & 0,885 & 0,915 & 0,559 & 0,408 \\
\hline $\mathrm{EI} 2 * * *)$ & 0,576 & & & & & & \\
\hline EI3 & 0,867 & 0,869 & & & & & \\
\hline EI4 & 0,884 & 0,890 & & & & & \\
\hline EI5 & 0,848 & 0,895 & & & & & \\
\hline $\mathrm{G}: \mathrm{G}$ & 1,000 & 1,000 & 1,000 & 1,000 & 1,000 & & \\
\hline
\end{tabular}

Tabel 4. Latent Variable Correlation

\begin{tabular}{llllll}
\hline & Att & SN & PBC & EE & EI \\
\hline SN & 0,504 & & & & \\
PBC & 0,669 & 0,512 & & & \\
EE & 0,554 & 0,444 & 0,425 & & \\
EI & 0,632 & 0,547 & 0,624 & 0,517 & \\
G & 0,044 & 0,096 & $-0,049$ & 0,018 & $-0,07$ \\
VAVE & 0,887 & 0,885 & 0,838 & 0,801 & 0,885 \\
\hline
\end{tabular}

Path coefficient pengaruh attitude terhadap entreprenurial intention sebesar 0,234 dengan t statistic sebesar 3,062 > 2,33 dan $p$-value sebesar 0,001 <0,01. Hasil ini menyimpulkan bahwa attitude berpengaruh positif signifikan terhadap entreprenurial intention. Dapat disimpulkan bahwa dengan attitude yang semakin positif, akan meningkatkan secara signifikan entreprenurial intention. Berdasarkan hasil ini $\mathrm{H}_{2}$ diterima.

Tabel 5. Path Coefficient

\begin{tabular}{lllr}
\hline & $\begin{array}{l}\text { Path } \\
\text { Coeff. }\end{array}$ & T-Stat & P-Val \\
\hline Att -> EI & 0,234 & $\left.3,062^{*}\right)$ & $\left.0,001^{*}\right)$ \\
SN -> EI & 0,188 & $\left.2,830^{*}\right)$ & $\left.0,002^{*}\right)$ \\
PBC -> EI & 0,261 & $\left.3,676^{*}\right)$ & $\left.0,000^{*}\right)$ \\
EE -> EI & 0,196 & $\left.3,523^{*}\right)$ & $\left.0,000^{*}\right)$ \\
Att * EE -> EI & 0,127 & 1,103 & 0,135 \\
SN * EE -> EI & 0,001 & 0,008 & 0,497 \\
PBC * EE -> EI & 0,044 & 0,450 & 0,326 \\
EE * G -> EI & $-0,013$ & 0,160 & 0,437 \\
G -> EI & $-0,077$ & 1,493 & 0,068 \\
\hline
\end{tabular}

Path coefficient dampak subjective norm terhadap entreprenurial intention sebesar 0,188 dengan $t$ statistic sebesar 2,830 $>2,33$ dan $p$-value sebesar 0,002 <0,01. Hasil ini menyimpulkan bahwa subjective norm berpengaruh positif signifikan terhadap entreprenurial intention. Ini menunjukkan bahwa subjective norm yang semakin tinggi, dapat meningkatkan entreprenurial intention secara signifikan. Berdasarkan hasil ini $\mathrm{H}_{3}$ diterima.

Path coefficient pengaruh perceived behavioral control terhadap entreprenurial intention sebesar 0,261 dengan $t$ statistic sebesar 3,676> 2,33 dan p-value sebesar $0,000<0,01$. Hasil ini menyimpulkan bahwa perceived behavioral control memberikan pengaruh positif signifikan terhadap entreprenurial intention. Perceived behavioral control yang semakin tinggi dapat disimpulkan mampu meningkatkan secara signifikan entreprenurial intention. Berdasarkan hasil ini $\mathrm{H}_{4}$ diterima.

Path coefficient pengaruh entrepreneurship education terhadap entreprenurial intention sebesar 0,196 dengan $t$ statistic sebesar 3,523> 2,33 dan $p$ value sebesar $0,000<0,01$. Hasil ini menyimpulkan bahwa entrepreneurship education berpengaruh positif signifikan terhadap entreprenurial intention. Dapat ditarik kesimpulan bahwa semakin tinggi entrepreneurship education, dapat 
meningkatkan entreprenurial intention secara signifikan. Berdasarkan hasil ini $\mathrm{H}_{1 \mathrm{a}}$ diterima. Entrepreneurship education terbukti tidak memoderasi dampak attitude, subjective norm dan perceived behavioral control pada entreprenurial intention dengan nilai $t$ statistic $<2,33$ masing-masing sebesar 1,103; 0,008 dan 0,450 , dan $p$-value $>0,01$ masingmasing sebesar 0,$135 ; 0,497$ dan 0,326. Hasil ini berarti entrepreneurship education yang semakin tinggi tidak memperkuat pengaruh positif attitude, subjective norm dan perceived behavioral control pada entreprenurial intention. Berdasarkan hasil ini $\mathrm{H}_{5 \mathrm{a}}, \mathrm{H}_{5 \mathrm{~b}}$ dan $\mathrm{H}_{5 \mathrm{c}}$ ditolak.

Pengaruh Gender terhadap entreprenurial intention tidak terbukti. Kesimpulan tersebut ditunjukkan dengan nilai $t$ statistic sebesar $1,493<2,33$ dan $p$-value sebesar 0,068 > 0,01. Gender juga terbukti tidak memoderasi pengaruh entrepreneurship education terhadap entreprenurial intention ditunjukkan dengan nilai $t$ statistic sebesar $0,160<2,33$ dan $p$-value sebesar 0,437> 0,01 . Hasil ini berarti pada mahasiswa maupun mahasiswi, pengaruh positif entrepreneurship education terhadap entreprenurial intention tidak berbeda signifikan. Pengaruh entrepreneurship education terhadap entreprenurial intention pada mahasiswi, tidak lebih rendah secara signifikan daripada pengaruh entrepreneurship education terhadap entreprenurial intention pada mahasiswa. Berdasarkan hasil ini $\mathrm{H}_{6 \mathrm{~b}}$ ditolak.

\section{Pembahasan}

Hasil pengujian memperlihatkan adanya pengaruh yang positif signifikan dari attitude terhadap entrepreneurial intention. Meskipun terdapat inkonsistensi terhadap penelitian terdahulu yang menunjukkan bahwa attitude berpengaruh negatif terhadap e-commerce (entrepreneurial) intention (Suryawirawan, 2020), hasil ini sejalan dengan serangkaian penelitian lain yang menunjukkan bahwa attitude memiliki dampak positif terhadap entrepreneurial intention (Al-Jubari, 2019a; Dinc \& Budic, 2016; Mahfud et al., 2020a).
Subjective norm ditemukan berpengaruh positif signifikan terhadap entrepreneurial intention. Temuan ini sejalan dengan sejumlah penelitian sebelumnya yang membuktikan pengaruh positif subjective norm terhadap entpreneurial intention (AlJubari, 2019b; Dinc \& Budic, 2016; Mahfud et al., 2020b; Suryawirawan, 2020).

Hasil pengujian diatas menyimpulkan terdapatnya pengaruh positif signifikan perceived behavioral control pada entrepreneurial intention. Hasil tersebut sejalan dengan serangkaian penelitian sebelumnya yang menyatakan bahwa perceived behavioral control menunjukkan dampak yang positif terhadap entrepreneurial intention (Al-Jubari, 2019b; Dinc \& Budic, 2016; Mahfud et al., 2020b; Suryawirawan, 2020).

Berdasarkan paparan diatas maka dapat disimpulkan bahwa entrepreneurship education memiliki pengaruh yang positif signifikan terhadap entrepreneurial intention. Ini mendukung hipotesis awal peneliti dan sejalan dengan serangkaian penelitian terdahulu yang menyatakan entrepreneurship education berpengaruh positif terhadap entrepreneurial intention (Anderson \& Jack, 2008; Athayde, 2009; Ferreira et al., 2012; Jun, 2016).

Penelitian ini tidak dapat membuktikan adanya efek moderasi dari entrepreneurship education pada pengaruh attitude, subjective norm dan perceived behavioral control terhadap entrepreneurial intention. Hasil ini konsisten dengan sejumlah penelitian terdahulu yang melihat entrepreneurship education sebagai variabel biasa yang berpengaruh terhadap entrepreneurial intention (Anderson \& Jack, 2008; Athayde, 2009; Ferreira et al., 2012; Jun, 2016).

Dari paparan diatas ditemukan hasil tidak adanya perbedaan yang signifikan antara entrepreneurial intention dari laki-laki dan perempuan. Meskipun hasil tersebut tidak sejalan dengan hipotesis awal peneliti serta penelitian sebelumnya yang menyatakan bahwa terdapat perbedaan antara entrepreneurial intention dari laki-laki dan perempuan (Nowiński et al., 2017; 
Suryawirawan, 2020), namun hasil tersebut didukung oleh penelitian sebelumnya yang menyatakan terdapatnya hasil yang serupa antara laki-laki dan perempuan pada niatan mereka untuk menjadi wirausaha setelah menempuh pendidikan kewirausahaan (LO et $a l ., 2012$ ). Hasil yang serupa ini disinyalir juga menjadi penyebab mengapa gender tidak dapat memoderasi pengaruh entrepreneurship education terhadap entrepreneurial intention seperti yang telah dibuktikan melalui hasil uji statistik diatas. Namun hasil tersebut konsisten dengan penelitian terdahulu yang juga tidak menemukan moderasi gender terhadap hubungan antara entrepreneurship education terhadap entrepreneurial intention (Kusmintarti et al., 2018).

Tidak adanya perbedaan yang signifikan antara entrepreneurial intention antara mahasiswa jenjang sarjana dan vokasi, memperlihatkan bahwa pada penelitian yang dilakukan, tidak ada perbedaan antara mahasiswa yang menempuh matakuliah praktikum kewirausahaan dengan yang tidak menempuh. Hal ini bertentangan dengan pernyataan sebelumnya bahwa kegiatan ekstrakurikuler, matakuliah opsional dan aktifitas praktikum terkait kewirausahaan, dapat mempengaruhi niatan berwirausaha seseorang (Arranz et al., 2017; Karimi et al., 2016; Piperopoulos \& Dimov, 2015).

Dari pemaparan diatas terkait pengaruh positif signifikan attitude pada entrepreneurial intention dapat ditarik sebuah kesimpulan bahwa semakin positif sikap seseorang terhadap aktifitas kewirausahaan, maka semakin tinggi niatan orang tersebut untuk menjadi wirausaha, dalam konteks penelitian ini, sikap positif dari mahasiswa akan meningkatkan keinginan mahasiswa tersebut untuk menjadikan kewirausahaan sebagai salah satu pilihan karir yang menjanjikan di masa depan. Berdasarkan temuan diatas terkait pengaruh positif signifikan subjective norm pada entrepreneurial intention juga dapat disimpulkan bahwa dukungan yang positif dari kalangan terdekat responden, yang dalam konteks penelitian ini adalah mahasiswa, akan meningkatkan niatan mahasiswa tersebut untuk menjadi seorang entrepreneur di masa depan. Tidak hanya itu, perceived behavioral control yang ditemukan berpengaruh positif signifikan terhadap entrepreneurial intention membuktikan bahwa kemudahan yang dirasakan mahasiswa yang menjadi responden pada penelitian ini, mampu meningkatkan niatan mahasiswa tersebut untuk menjadi wirausaha di masa depan. Pengaruh positif signifikan entrepreneurship education pada entrepreneurial intention juga menghasilkan kesimpulan bahwa menempuh baik matakuliah kewirausahaan maupun praktikum kewirausahaan, memberikan dampak yang signifikan terhadap niatan mahasiswa di Surabaya, untuk menjadi wirausaha.

Tidak adanya efek moderasi entrepreneurship education pada hubungan antara attitude, subjective norm serta perceived behavioral control terhadap entrepreneurial intention menunjukkan bahwa pendidikan yang diperoleh mahasiswa tidak mampu meningkatkan attitude, subjective norm dan perceived behavioral control, yang memiliki peran dalam membentuk niatan seseorang untuk menjadi wirausaha.

Salah satu faktor tidak ditemukannya perbedaan yang signifikan adalah kekurangan pada kurikulum praktikum kewirausahaan yang diberikan, sehingga terlepas dari keunggulan yang dimiliki mahasiswa ataupun mahasiswi, baik jenjang vokasi maupun sarjana, hal tersebut tidak cukup menumbuhkan niatan yang lebih besar dalam diri mereka. Faktor lain yang mungkin menjadi penyebab tidak terlihatnya perbedaan yang signifikan antara kedua jenjang, adalah sebagian dari pertemuan pada matakuliah praktikum yang dilakukan secara online akibat pandemi Covid-19, ini dapat menyebabkan pengalaman mahasiswa dan mahasiswi terkait dengan suasana kreasi dan inovasi yang ditawarkan pada matakuliah praktikum kewirausahaan menjadi berkurang. 


\section{Kesimpulan}

Berdasarkan pemaparan pada bagian sebelumnya, dapat disimpulkan bahwa attitude, subjective norm dan perceived behavioral control berpengaruh positif signifikan terhadap entrepreneurial intention, entrepreneurship education berpengaruh positif signifikan terhadap entrepreneurial intention, entrepreneurship education tidak terbukti memoderasi pengaruh variable dari theory of planned behavior variables terhadap entrepreneurial intention, gender tidak terbukti memoderasi pengaruh variable entrepreneurship education terhadap entrepreneurial intention, tidak terdapat perbedaan entrepreneurial intention antara mahasiswa dengan mahasiswi dan tidak terdapat perbedaan entrepreneurial intention baik mahasiswa program sarjana maupun vokasi.

Penelitian ini dilakukan terhadap sampel sejumlah 220 orang, penelitian yang lebih lanjut dapat dilakukan pada lebih banyak responden sehingga dapat mewakili dengan lebih baik populasi dan sampel yang digunakan. Penelitian ini juga dilakukan hanya dikalangan mahasiswa, penelitian yang akan datang diharapkan mampu melibatkan lebih banyak elemen masyarakat yang lain. Terdapat inkonsistensi hasil pengujian pada beberapa variabel didalam penelitian ini dengan penelitian terdahulu yang menguji hal serupa, penelitian yang akan datang dapat dilakukan untuk mengkonfirmasi lebih lanjut hasil tersebut.

\section{DAFTAR PUSTAKA}

Ajzen, I. (1991). The theory of planned behavior. Organizational Behavior and Human Decision Processes, 50(2), 179211.

https://doi.org/https://doi.org/10.1016/0 749-5978(91)90020-T

Ajzen, I. (2001). Nature and Operation of Attitudes. Annual Review of Psychology, 52 , 27-58. https://doi.org/10.1146/annurev.psych.5 2.1.27
Ajzen, I., \& Fishbein, M. (1980). Understanding Attitudes and Predicting Social Behavior. Prentice-Hall.

Al-Jubari, I. (2019a). College students' entrepreneurial intention: Testing an integrated model of SDT and TPB. Sage Open, 9(2), 2158244019853467.

Al-Jubari, I. (2019b). College students' entrepreneurial intention: Testing an integrated model of SDT and TPB. Sage Open, 9(2), 2158244019853467.

ALOULOU, W. J. (2016). Predicting Entrepreneurial Intentions of Final Year Saudi University Business Students by applying the Theory of Planned Behaviour. Journal of Small Business and Enterprise Development, 23, 11421164. https://doi.org/10.1108/JSBED02-2016-0028

Anderson, A., \& Jack, S. (2008). Role typologies for enterprising education: The professional artisan? Journal of Small Business and Enterprise Development, 15 https://doi.org/10.1108/1462600081087 1664

APJII. (2017). Infografis Penetrasi \& Perilaku Pengguna Internet Indonesia.

Armitage, C. J., \& Conner, M. (2001). Efficacy of the theory of planned behaviour: A meta-analytic review. British Journal of Social Psychology, 40(4), 471-499.

Arranz, N., Ubierna, F., Arroyabe, M. F., Perez, C., \& de Arroyabe, J. C. (2017). The effect of curricular and extracurricular activities on university students' entrepreneurial intention and competences. Studies in Higher Education, 42(11), 1979-2008.

Athayde, R. (2009). Measuring enterprise potential in young people. Entrepreneurship Theory and Practice, 33(2), 481-500.

Atmaja, A. T., \& Margunani, M. (2016). Pengaruh Pendidikan Kewirausahaan dan Aktivitas Wirausaha terhadap Minat Berwirausaha Mahasiswa Universitas Negeri Semarang. Economic Education Analysis Journal, 5(3), 774. 
Badan Pusat Statistik. (2017). Survei Angkatan Kerja Nasional 2016 Agustus.

Badan Pusat Statistik. (2019). Berita Resmi Statistik 5 November 2019.

Bae, T. J., Qian, S., Miao, C., \& Fiet, J. O. (2014). The relationship between entrepreneurship education and entrepreneurial intentions: A metaanalytic review. Entrepreneurship Theory and Practice, 38(2), 217-254. https://doi.org/https://doi.org/10.1111/et ap. 12095

Billah, H. M. (2019). Kewirausahaan Kunci Pertumbuhan Ekonomi Indonesia. Liputan 6. https://www.liputan6.com/regional/read /4079235/kewirausahaan-kuncipertumbuhan-ekonomi-indonesia

Bird, B. (1988). Implementing Entrepreneurial Ideas: The Case for Intention. The Academy of Management Review, https://doi.org/10.2307/258091

Bryant, P. T. (2006). Improving entrepreneurial education through selfregulatory skills. VentureWell. Proceedings of Open, the Annual Conference, 279.

Chen, C. C., Greene, P. G., \& Crick, A. (1998). Does entrepreneurial selfefficacy distinguish entrepreneurs from managers? Journal of Business Venturing, 13(4), 295-316.

Chin, W. W. (1998). The Partial Least Squares Approach to Structural Equation Modeling. Advances in Hospitality and Leisure.

Dinc, M., \& Budic, S. (2016). The Impact of Personal Attitude, Subjective Norm, and Perceived Behavioural Control on Entrepreneurial Intentions of Women. Eurasian Journal of Business and Economics, 2016, 23-35. https://doi.org/10.17015/ejbe.2016.017. 02

Ditjen Pendidikan Vokasi. (2020). Rencana Strategis (Renstra) Direktorat Jendral Pendidikan Vokasi 2020-2024.

Duval-Couetil, N., Shartrand, A., \& Reed, T. (2016). The role of entrepreneurship program models and experiential activities on engineering student outcomes. Advances in Engineering Education, $\quad 5(1), \quad \mathrm{n} 1$. http://files.eric.ed.gov/fulltext/EJ10905 82.pdf

Eagly, A. H., \& Chaiken, S. (1993). The psychology of attitudes. Harcourt brace Jovanovich college publishers.

Falk, R. F., \& Miller, N. B. (1992). A Primer for Soft Modeling. University of Akron Press.

Ferreira, J. J., Raposo, M., Rodrigues, R., Dinis, A., \& Paço, A. (2012). A Model of Entrepreneurial Intention: An Application of the Psychological and Behavioral Approaches. Journal of Small Business and Enterprise Development, 19, 424-440. https://doi.org/10.1108/1462600121125 0144

Fiore, E., Sansone, G., Paolucci, E., \& Xi, C. (2019). Entrepreneurship Education in a Multidisciplinary Environment: Evidence from an Entrepreneurship Programme Held in Turin. Administrative Sciences. https://doi.org/10.3390/admsci9010028

Fishbein, M., \& Ajzen, I. (1975). Belief, attitude, intention and behaviour: An introduction to theory and research, 27.

Gartner, W., \& Katz, J. (1988). Properties of Emerging Organizations. The Academy of Management Review, 13. https://doi.org/10.2307/258090

GEM. (2018). Global entrepreneurship monitor - 2017/2018 global report, global entrepreneurship research association (GERA).

Hair, J. F., Ringle, C. M., Hult, G. T. M., \& Sarstedt, M. (2014). A Primer on Partial Least Squares Structural Equation Modeling. SAGE Publications, Inc.

Hartono, H. (2021). Changing University Students' Mindset: From Job Seekers to Job Creators. Technium Social Sciences Journal, 18. https://doi.org/10.47577/tssj.v18i1.3026

Hendarman, --. (2011). Kajian Kebijakan PMW (Program Mahasiswa Wirausaha). 
Jurnal Pendidikan Dan Kebudayaan, 17(6), 635-646. https://doi.org/https://doi.org/10.24832/j pnk.v17i6.55

Henry, C., Hill, F., \& Leitch, C. (2005). Entrepreneurship Education and Training: Can Entrepreneurship Be Taught? Part II. Education + Training, 47 , 98-111. https://doi.org/10.1108/0040091051058 6524

Hien, D. T. T., \& Cho, S. E. (2018). Relationship between entrepreneurship education and innovative start-up intentions among university students. International Journal of Entrepreneurship, 22(3), 1-16. https://www.abacademies.org/articles/re lationship-between-entrepreneurshipeducation-and-innovative-startupintentions-among-university-students7456.html

Hoang, G., Le, T. T. T., Tran, A. K. T., \& Du, T. (2021). Entrepreneurship education and entrepreneurial intentions of university students in Vietnam: the mediating roles of self-efficacy and learning orientation. Education + Training, 63(1), 115-133. https://doi.org/10.1108/ET-05-20200142

Hua, S., \& Ren, Z. (2020). "Online+ Offline" course teaching based on case teaching method: a case study of entrepreneurship education course. International Journal of Emerging Technologies in Learning (IJET), 15(10), 69-85. https://doi.org/https://doi.org/10.3991/ij et.v15i10.13999

Johnstone, L., Monteiro, M. P., Ferreira, I., Westerlund, J., Aalto, R., \& Marttinen, J. (2018). Language ability and entrepreneurship education: Necessary skills for Europe's start-ups? Journal of International Entrepreneurship, 16(3), 369-397.

https://doi.org/https://doi.org/10.1007/s 10843-018-0230-y

Jun, H. Y. (2016). Self-Efficacy as Moderator in Entrepreneurship Education and
Entrepreneurial Intention: Comparison between Korean and Chinese University Students. The Journal of Small Business Innovation, 19(1), 17-35.

Karimi, S., Biemans, H. J. A., Lans, T., Chizari, M., \& Mulder, M. (2016). The impact of entrepreneurship education: A study of Iranian students' entrepreneurial intentions and opportunity identification. Journal of Small Business Management, 54(1), 187-209.

Krueger Jr, N. F., Reilly, M. D., \& Carsrud, A. L. (2000). Competing models of entrepreneurial intentions. Journal of Business Venturing, 15(5-6), 411-432.

Kundu, S., \& Rani, S. (2008). Human resources' entrepreneurial attitude orientation by gender and background: A study of Indian Air Force trainees. International Journal of Management and Enterprise Development - Int J Manag Enterprise Dev, 5. https://doi.org/10.1504/IJMED.2008.01 5908

Kusmintarti, A., Ismanu, S., \& Riwajanti, N. (2018). Gender as a Moderator of the Influence Entrepreneurial Education and Entrepreneurial Characteristics on Entrepreneurial Intention. International Journal of Engineering \& Technology, $7, \quad 469$. https://doi.org/10.14419/ijet.v7i3.30.18 360

Lelliezzia, P., Musadeq, A., \& Arik, P. (2020). Effect of Entrepreneurship Education and Entrepreneurial Characters Toward Entrepreneurial Intention with Business Motivation as Intervening. Wacana Journal of Social and Humanity Studies, 23(3).

Liñán, F., \& Chen, Y.-W. (2009). Development and Cross-Cultural Application of A Specific Instrument to Measure Entrepreneurial Intentions. Entrepreneurship Theory and Practice, 33, 593-617. https://doi.org/10.1111/j.15406520.2009.00318.x 
LO, C., Sun, H., \& Law, K. (2012). Comparing the Entrepreneurial Intention between Female and Male Engineering Students: Implications for Entrepreneurship Education. Journal of Women's Entrepreneurship and Education, 1, 28-50.

Lucky, E. O., \& Minai, M. S. (2014). A qualitative study of the attitudes of the would-be graduates towards entrepreneurial intentions. Entrepreneurship and Innovation Management Journal, Ii, 2, 128-134.

Mahfud, T., Triyono, M. B., Sudira, P., \& Mulyani, Y. (2020a). The influence of social capital and entrepreneurial attitude orientation on entrepreneurial intentions: the mediating role of psychological capital. European Research on Management and Business Economics, 26(1), 33-39.

Mahfud, T., Triyono, M. B., Sudira, P., \& Mulyani, Y. (2020b). The influence of social capital and entrepreneurial attitude orientation on entrepreneurial intentions: the mediating role of psychological capital. European Research on Management and Business Economics, 26(1), 33-39.

Matlay, H. (2005). Entrepreneurship Education in UK Business Schools: Conceptual, Contextual and Policy Considerations. Journal of Small Business and Enterprise Development, 12 , 627-643. https://doi.org/10.1108/1462600051062 8270

Nguyen, T. T., Nguyen, L. T. P., Phan, H. T. T., \& Vu, A. T. (2021). Impact of Entrepreneurship Extracurricular Activities and Inspiration on Entrepreneurial Intention: Mediator and Moderator Effect. SAGE Open, 11(3). https://doi.org/10.1177/2158244021103 2174

Nowiński, W., Haddoud, M., Lančarič, D., Egerová, D., \& Czeglédi, C. (2017). The impact of entrepreneurship education, entrepreneurial self-efficacy and gender on entrepreneurial intentions of university students in the Visegrad countries. Studies in Higher Education, 44 , $1-19$. https://doi.org/10.1080/03075079.2017. 1365359

Ozaralli, N., \& Rivenburgh, N. K. (2016). Entrepreneurial intention: antecedents to entrepreneurial behavior in the USA and Turkey. Journal of Global Entrepreneurship Research, 6(1), 3.

Piperopoulos, P., \& Dimov, D. (2015). Burst bubbles or build steam? Entrepreneurship education, entrepreneurial self-efficacy, and entrepreneurial intentions. Journal of Small Business Management, 53(4), 970-985.

Pittaway, L., \& Cope, J. (2007). Entrepreneurship Education: A Systematic Review of the Evidence. International Small Business Journal: Researching Entrepreneurship, 25(5). https://doi.org/10.1177/0266242607080 656

Rahayu, N. (2019). Pertumbuhan ECommerce Pesat di Indonesia. Warta Ekonomi.

https://www.wartaekonomi.co.id/read21 6302/pertumbuhan-e-commerce-pesatdi-indonesia.html

Rizkinaswara, L. (2018). 1000 Startup Digital. Direktorat Jenderal Aplikasi Informatika.

https://aptika.kominfo.go.id/2018/11/10 00-startup-digitall/

Shook, C., \& Bratianu, C. (2010). Entrepreneurial intent in a transitional economy: An application of the theory of planned behavior to Romanian students. International Entrepreneurship and Management Journal, 6, 231-247. https://doi.org/10.1007/s11365-0080091-2

Stokes, D., Wilson, N., \& Mador, M. (2010). Entrepreneurship. Cengage Learning.

Suryawirawan, O. A. (2020). Theory of Planned Behavior Approach and Gender Differences on Students' Intention to Practice Online Business. Jurnal Dinamika Manajemen, 10, 138-147. 
https://doi.org/10.15294/jdm.v10i2.193

98

Susilaningsih, --. (2015). PENDIDIKAN

KEWIRAUSAHAAN DI

PERGURUAN TINGGI:

PENTINGKAH UNTUK SEMUA

PROFESI? Jurnal Economia, 11(1), 9. https://doi.org/https://doi.org/10.21831/ economia.v11i1.7748

UKM Indonesia. (2019). Bantuan Pemerintah bagi Wirausaha Pemula Tahun 2019. UKM Indonesia.

https://www.ukmindonesia.id/bacadeskripsi-program/106\#: :text=Dalam rangka menumbuhkan wirausaha pemula,000 untuk masing-masing WP

Xiaoxing, Q. (2020). Research on Innovation and Entrepreneurship Education. Higher Education Research, 5(6), 209. https://doi.org/10.11648/j.her.20200506 .11

Yang, J. (2013). The Theory of Planned Behavior and Prediction of Entrepreneurial Intention Among Chinese Undergraduates. Social Behavior and Personality: An International Journal, 41 . https://doi.org/10.2224/sbp.2013.41.3.3 67 